\title{
Teachers Voices: A Qualitative Study on Burnout in the Portuguese Educational System
}

\author{
Ana Isabel Mota ${ }^{1, *(\mathbb{D})}$, João Lopes ${ }^{1}\left(\mathbb{D}\right.$ and Célia Oliveira ${ }^{2}$ (I) \\ 1 School of Psychology, University of Minho, 4710-057 Braga, Portugal; joaols@psi.uminho.pt \\ 2 HEI-Lab: Digital Human-Environment Interaction Lab, Lusófona University of Porto, \\ 4000-098 Porto, Portugal; celia.oliveira@ulp.pt \\ * Correspondence: anaisabelmota@hotmail.com
}

Citation: Mota, A.I.; Lopes, J.; Oliveira, C. Teachers Voices: A Qualitative Study on Burnout in the Portuguese Educational System. Educ. Sci. 2021, 11, 392. https://doi.org/ 10.3390/educsci11080392

Academic Editor: Neil Gordon

Received: 29 June 2021

Accepted: 28 July 2021

Published: 31 July 2021

Publisher's Note: MDPI stays neutral with regard to jurisdictional claims in published maps and institutional affiliations.

Copyright: (c) 2021 by the authors. Licensee MDPI, Basel, Switzerland. This article is an open access article distributed under the terms and conditions of the Creative Commons Attribution (CC BY) license (https:// creativecommons.org/licenses/by/ $4.0 /)$.
Abstract: Teaching has been identified as an environment of extreme physical, mental, and cognitive demand for teachers and is one of the careers where burnout levels are the highest. This qualitative study aims to (i) understand the importance of personal, organizational, and classroom dimensions concerning the Portuguese education system, (ii) and how these dimensions contribute to burnout in Portuguese teachers from different teaching levels. Semi-structured interviews were conducted with twenty-six primary and high school teachers. Results offer insights on the impact that different variables have on teachers' burnout. The content analysis suggests that organization is the most relevant dimension contributing to teachers' burnout. On the other hand, the classroom category appears to be the most challenging context for teachers to manage. The results highlight the need to consider the dynamics and interdependency between personal, organizational, and classroom dimensions in the development and prevalence of burnout.

Keywords: burnout syndrome; teachers; risk factors; mental health; school context; qualitative research

\section{Introduction}

Mental and physical well-being depend on how well individuals can handle the psychosocial, contextual, and physical challenges and demands of their environments [1]. Although stress is a necessary and sometimes useful physiologic response, continuous exposure to high levels of occupational stress may lead to burnout [2].

Burnout is a psychosocial phenomenon characterized by emotional exhaustion, depersonalization, and diminished personal fulfilment [3]. Over the past two decades, burnout in teachers has been recognized as a severe professional problem, affecting teachers' motivation and job satisfaction, with consequences for not only students' learning and behavior, but also the broader school environment [4,5]. Compared with other careers, teaching has been identified as one of the careers with the highest levels of perceived stress [6]. According to [2], school as a professional environment is characterized by several contexts susceptible to emotional exhaustion that vary from school to school, and within the same school. The concept of "professional environment demands" refers to physical, social, or organizational attributes of a professional context that require prolonged physical and/or mental effort [7].

Previous research has identified several variables that enable the characterization of extreme mental and cognitive demands present in schools. In Portuguese schools specifically, previous studies suggest that variables associated with teachers' burnout can be better understood when evaluated across three major dimensions: personal, organizational, and classroom [8]. 


\subsection{Individual Intrinsic Variables}

Individual resources such as emotional competencies and coping strategies play an essential role in burnout, because they influence the way teachers perceive and respond to their daily challenges and demands [9-11]. Likewise, several authors have observed that a teachers' major contributing factor to teacher exhaustion is their personal inability to manage the plurality of roles and myriad tasks demanded of them by schools and families [12].

\subsection{School Context Attributes}

The peculiarities of the education system and variables associated with the school environment appear to have an even more dominant role in the prevalence and levels of burnout [13]. These attributes include precarious employment contracts, limited career development opportunities, time pressure, salaries, physical conditions, demands, excessive workload, the multiplicity of tasks, and bureaucracy $[7,10,12,14,15]$.

The variables associated with the school environment deal with perceptions related to the overall school climate and result from interactions in the school context. Several authors claim a lack of emphasis on variables regarding interpersonal relationships, such as the perceived quality of the relationships between work peers, with school principals, or the lack of morale in the workplace [16]. Studies on the perceptions of organizational support show that teachers who perceive less support from their peers and school principals tend to experience higher levels of stress and burnout [17]. The impact of the perceived support also seems to be correlated with other organizational variables, such as the workload [15].

The characteristics of different levels of education also appear to be paramount to understanding the development of burnout, because different teaching levels require distinct teaching techniques and are intended for different audiences [18]. However, results on teachers' burnout among different teaching levels are inconsistent. For example, in a study conducted with Brazilian teachers, elementary school teachers showed the lowest levels of emotional exhaustion and depersonalization and the highest levels of job satisfaction [19]. In another study in Israel, teachers of the youngest students reported the highest levels of burnout [20]. For instance, [21] did not find considerable discrepancies in the burnout levels among Australian elementary and high school teachers.

\subsection{Classroom and Student Characteristics}

In the classroom context, student misbehavior is regarded as the main culprit for teacher burnout [22]. Other contributing factors include students' lack of motivation, student heterogeneity in performance and competence skills, and class size [11,23].

Parents also seem to interfere with teachers' perception of well-being. Earlier studies suggest that parents' pressure on teachers, and teachers' perception of improper parental educational practices directly contribute to teachers' burnout $[2,24]$.

\subsection{Present Study}

In the current study, burnout is conceived as a subjective experience stemming from self-interpretation and self-evaluation of the context in which individuals are integrated. The sense of stress and burnout is determined by an individual's evaluation of the circumstances and challenges presented to them and the cognitive resources they possess [25].

The present study explores how a set of variables, already identified as relevant for the development and prevalence of burnout in teachers, applies to a sample of Portuguese teachers. Specifically, it aims to understand (i) the relative importance of personal, organizational, and classroom dimensions associated with the Portuguese educational context, and (ii) how they contribute to burnout in Portuguese teachers from different teaching levels.

\section{Materials and Methods}

This is a qualitative study that used semi-structured interviews "to gain insights into a person's subjective experiences, opinions and motivations" [26], p. 3. Content analysis was 
used as a research method. Frequency counting was also used as part of the data analysis to support the interpretation of results (i.e., to indicate the prevalence of a particular category or subcategory in the interviews in this group of teachers) [27].

\subsection{Participants}

Initial contact was established with school principals from three schools located in the north of Portugal. School principals were asked to forward our calls to teachers who, in their opinion, showed signs of significant stress and exhaustion. It was thus intended to incorporate participants that could be considered good insiders regarding the burnout phenomenon.

Participants were 26 teachers between 48 and 63 years old $(M=56.7, D P=3.9) ; 21$ were female $(80.8 \%)$ and 5 were male $(19.2 \%)$. Their teaching experience ranged from 17 to 37 years $(M=29, D P=4.4)$. These participants taught in the 1st cycle of elementary school $(n=4,15.4 \%)$, 2nd cycle of elementary school $(n=5,19.2 \%)$, 3rd cycle of elementary school $(n=7,26.9 \%)$, high school $(n=4,15.4 \%)$, and in the 3rd cycle of elementary school and high school $(n=6,23.1 \%)$, in public schools in the north of continental Portugal. The Portuguese education system is organized into two primary sequential levels of compulsory education: (a) elementary school, including the 1st cycle (1st to 4th grade), 2nd cycle (5th and 6th grades), and 3rd cycle (7th to 9th grade); and (b) high school (10th to 12th grade). Two of the teachers were on medical leave with a diagnosis of psychological exhaustion.

\subsection{Procedures}

An interview script was developed by experienced researchers in Educational and School Psychology. Four initial interviews were conducted, one for each teaching level (1st cycle, 2nd cycle, 3rd cycle, and high school) to test the suitability of the script's content. This procedure provided data about emerging issues and informed minor improvements to the initial interview script; for example, a question about the students' parents was then included because this subject surfaced during the initial interviews. The same interview script was used for the different teaching cycles given the similar emerging issues but varied in the importance of each item. The final version of the interview script was again tested and ratified by the researchers.

Participants were contacted by phone or email, the terms and conditions of the study were presented, and interviews were scheduled following the participants' availability. Interviews were recorded after informed consent was given. Confidentiality was assured, and participants were informed that they were free to end their participation in the study at any time. In the interview transcripts, all data associated with the participant's identity (e.g., name, location) were eliminated to ensure data anonymity.

\subsection{Measures}

The semi-structured interview script was developed to explore variables associated with personal, organizational, and classroom dimensions based on a literature review. The interviews started with a generic question ("What is a normal day like for you as a teacher?"), followed by open questions regarding personal (e.g., "How do you manage your personal and professional life?"), organizational (e.g., "Generally speaking, are you happy with the current Portuguese Education System?"), and classroom dimensions (e.g., "How do you manage the classroom?"). The script consisted of twelve questions whose order was not strictly maintained, allowing the participants to answer in a free and unrestricted manner and thereby provide the interviewer with a deeper understanding of the subject.

\subsection{Data Analysis}

Interviews were transcribed and subjected to a content analysis process according to the three stages proposed by [28]: pre-analysis, content analysis, and output handling, deduction, and interpretation. The pre-analysis process produced a grid of categories and 
subcategories. This grid was initially applied to interviews by teaching level (1st cycle, 2nd cycle, 3rd cycle, and high school) to test data adjustment. This procedure led to the elimination or combination of some of the subcategories. Given the finalized grid of categories and subcategories, the twenty-six interviews were coded, and the interrater agreement was implemented. The coding of categories and subcategories was performed manually by two raters, with experience in research in the education field, who carried out the data analysis independently. Disagreements were tie-broken by a third judge, an expert in the professional development of teachers.

Cohen's kappa coefficient analyses were conducted to verify the reliability of and validate the grid of categories and subcategories [29]. Mean values of Cohen's kappa coefficient showed an "almost perfect agreement" $(k=0.81-1)$ for the twenty-six interviews $(k=0.88)$ and for the three large dimensions $(k=0.90)$. The robust reliability indices of the different Cohen's kappa coefficients ensured objectiveness and consistency throughout the content analysis process.

Statistic descriptive analysis and frequency analysis were conducted using Microsoft Excel.

\section{Results}

\subsection{Grid of Categories and Subcategories}

Content analysis generated a total of ten categories and forty-three subcategories, all mutually exclusive. The personal dimension included personal, social, academic, and professional attributes and the perception of physical, emotional, and mental capabilities (Table 1). The organizational dimension represented characteristics and idiosyncrasies of the Portuguese educational system and included variables of a relational nature (Table 2). The classroom dimension included the characteristics of the classroom context and the variables directly or indirectly related to students, parents, or the value system (Table 3).

Table 1. Categories and subcategories of the personal dimension $(n=26)$.

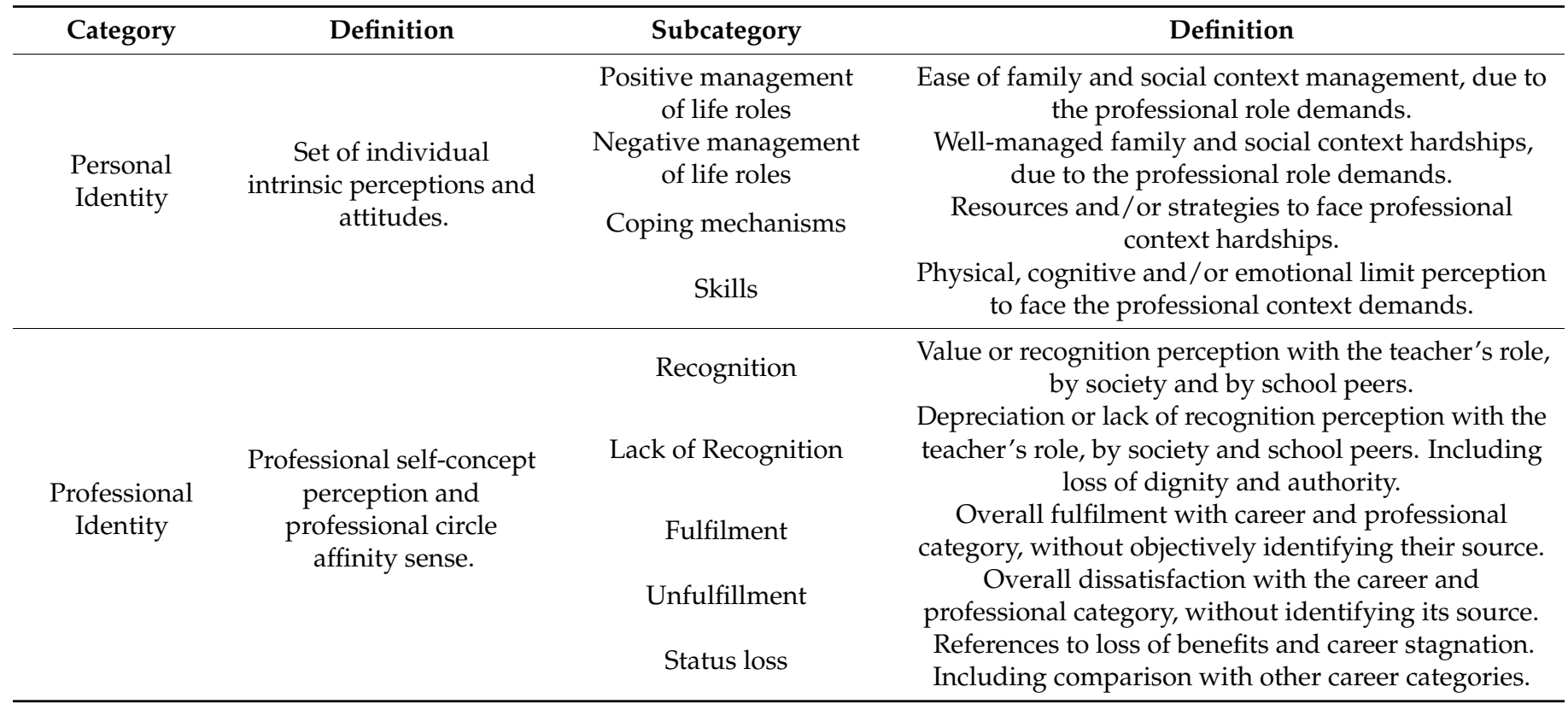

\subsection{Frequency of Categories and Subcategories}

Absolute, average, and relative frequency analyses were conducted to understand the representativeness of the dimensions (Table 4) and the categories and subcategories (Table 5). Overall, the organizational dimension was the most frequently mentioned by teachers $(39.1 \%)$, followed by the classroom $(37.7 \%)$ and personal $(23.6 \%)$ dimensions. When considering the different teaching levels, the classroom dimension was the most relevant for teachers of the 1 st $(43.5 \%)$ and 2 nd $(41 \%)$ cycles of basic education. 
Table 2. Categories and subcategories of the organizational dimension $(n=26)$.

\begin{tabular}{|c|c|c|c|}
\hline Category & Dimension & Subcategory & Definition \\
\hline $\begin{array}{l}\text { School } \\
\text { System }\end{array}$ & $\begin{array}{l}\text { Portuguese school } \\
\text { system properties. }\end{array}$ & $\begin{array}{l}\text { Programs } \\
\text { Teachers' workload } \\
\text { Students' workload } \\
\text { Overall Bureaucracy } \\
\text { Teachers' evaluation } \\
\text { School evaluation } \\
\text { Legislation }\end{array}$ & $\begin{array}{l}\text { Perceived imbalance between the school program } \\
\text { requirements and the curricular goals, and the time } \\
\text { available to teach that which matters. } \\
\text { Reference to the teachers' excessive workload and the } \\
\text { perceived imbalance between the available time for } \\
\text { scholar and not-scholar components. } \\
\text { Reference to the students' excessive workload. } \\
\text { Includes the free time during school hours cessation. } \\
\text { Amount of bureaucracy associated with teaching. } \\
\text { Includes perceived worthlessness and fatigue. } \\
\text { Reference to external and internal teachers' evaluation. } \\
\text { Reference to internal and external school evaluations. } \\
\text { Negative impact of the continuous legal changes in } \\
\text { teaching. Includes the perception of inadequacy of the } \\
\text { law to the effective school context. }\end{array}$ \\
\hline $\begin{array}{l}\text { School } \\
\text { context }\end{array}$ & $\begin{array}{c}\text { School context properties } \\
\text { where the person } \\
\text { is integrated. }\end{array}$ & $\begin{array}{c}\text { Extra activities } \\
\text { School circumstances } \\
\text { Specific Bureaucracy }\end{array}$ & $\begin{array}{l}\text { Dissatisfaction with the timetable structure, } \\
\text { which makes it harder to mediate between } \\
\text { professional and personal life, and teachers' mingling. } \\
\text { Performance in tasks or duties not directly related to } \\
\text { content teaching. } \\
\text { Poor physical characteristics of the school space and } \\
\text { shortage of human resources. } \\
\text { Bureaucracy rise perception specific to that } \\
\text { school context. }\end{array}$ \\
\hline $\begin{array}{c}\text { School } \\
\text { atmosphere }\end{array}$ & $\begin{array}{l}\text { Relationship dimension, } \\
\text { contributing to } \\
\text { the perceived } \\
\text { school atmosphere. }\end{array}$ & $\begin{array}{l}\text { Organizational injustice } \\
\text { Positive relationship } \\
\text { with peers } \\
\text { Negative relationship } \\
\text { with peers } \\
\text { Positive relationship } \\
\text { with principals } \\
\text { Negative relationship } \\
\text { with principals }\end{array}$ & $\begin{array}{c}\text { Injustice perception stemming from hierarchical } \\
\text { superior decisions, compared to peers. Including } \\
\text { retaliation references. } \\
\text { Peer relationship quality perception. } \\
\text { Degrading or lack of peer relationship perception. } \\
\text { Relationship between teachers and school principals' } \\
\text { quality perception. } \\
\text { Perception of degrading or lack of relationships } \\
\text { between teachers and school principals. }\end{array}$ \\
\hline Limitations & $\begin{array}{l}\text { Teacher-perceived } \\
\text { limitations on } \\
\text { their performance. }\end{array}$ & Lack of autonomy & $\begin{array}{l}\text { Negative impact of the involvement in school projects. } \\
\text { Includes external school image concerns. } \\
\text { Perception of loss of autonomy in decision making } \\
\text { (i.e., grade assignments) and lack of freedom } \\
\text { of expression. } \\
\text { Perception of financial school priorities, limiting } \\
\text { teachers' roles and response. }\end{array}$ \\
\hline
\end{tabular}

Table 3. Categories and subcategories of the classroom dimension $(n=26)$.

\begin{tabular}{cccc}
\hline Category & Definition & Subcategory & Definition \\
\hline Classroom & $\begin{array}{c}\text { Classroom context } \\
\text { exclusive attributes. }\end{array}$ & $\begin{array}{c}\text { Management } \\
\text { Teaching content } \\
\text { Interruptions }\end{array}$ & $\begin{array}{c}\text { Indiscipline and disruptive student behaviors. } \\
\text { Classroom managemt and teaching strategies set } \\
\text { by teachers. }\end{array}$ \\
& Climate & $\begin{array}{c}\text { Perception of content teaching time. } \\
\text { Percentage of time not dedicated to content teaching } \\
\text { (i.e., Indiscipline). }\end{array}$ \\
& Class & $\begin{array}{c}\text { Perception of the classroom climate, characterized by } \\
\text { the student-teacher relationships. } \\
\text { Class attributes, including the number of students per } \\
\text { class and students' heterogeneity. }\end{array}$ \\
\hline
\end{tabular}


Table 3. Cont.

\begin{tabular}{|c|c|c|c|}
\hline Category & Definition & Subcategory & Definition \\
\hline Students & $\begin{array}{l}\text { Individual and student's } \\
\text { family attributes. }\end{array}$ & $\begin{array}{l}\text { Family structure } \\
\text { Development } \\
\text { Motivation }\end{array}$ & $\begin{array}{l}\text { Family structure of the students and their } \\
\text { social-economical context. } \\
\text { Cognitive and intellectual student } \\
\text { development perception. } \\
\text { Students' motivation and attention perception. }\end{array}$ \\
\hline Parents & Parents' attributes. & $\begin{array}{l}\text { Positive relationship } \\
\text { with parents } \\
\text { Pressure } \\
\text { Education }\end{array}$ & $\begin{array}{l}\text { Teacher-guardian relationship quality. } \\
\text { Parents' power and pressure on teachers' and school } \\
\text { principals' perception, and its impact. } \\
\text { Perception inadequate schooling practices and degree of } \\
\text { involvement from parents in the student's school life. }\end{array}$ \\
\hline Society & $\begin{array}{l}\text { Abstract nature attributes } \\
\text { from the individual } \\
\text { unique experience. }\end{array}$ & $\begin{array}{l}\text { Values } \\
\text { Mission }\end{array}$ & $\begin{array}{l}\text { Perception of loss of values from society, ethic and code } \\
\text { of conduct, such as citizenship, solidarity or respect. } \\
\text { Perception loss mission from the school and loss of the } \\
\text { teaching purpose. Includes perceptions of negative } \\
\text { evolutions of the school system (i.e., compared with } \\
\text { the past). }\end{array}$ \\
\hline
\end{tabular}

Table 4. Frequency of answers per dimension.

\begin{tabular}{cccccccccc}
\hline \multirow{2}{*}{ Dimension } & \multicolumn{2}{c}{$\begin{array}{c}\text { Total Sample } \\
(\boldsymbol{n}=\mathbf{2 6})\end{array}$} & \multicolumn{2}{c}{$\begin{array}{c}\mathbf{1 C B E} \\
(\boldsymbol{n}=\mathbf{4})\end{array}$} & \multicolumn{2}{c}{$\begin{array}{c}\mathbf{2 C B E} \\
(\boldsymbol{n}=\mathbf{5})\end{array}$} & \multicolumn{2}{c}{$\begin{array}{c}\text { 3CBE and SE } \\
(\boldsymbol{n}=\mathbf{1 7})\end{array}$} \\
\cline { 2 - 10 } & $\mathbf{A b F}$ & $\mathbf{A F}$ & $\mathbf{A b F}$ & $\mathbf{A F}$ & $\mathbf{A b F}$ & $\mathbf{A F}$ & $\mathbf{A b F}$ & $\mathbf{A F}$ \\
\hline Personal & 558 & $23.6 \%$ & 99 & $22.9 \%$ & 85 & $24.7 \%$ & 375 & $23.6 \%$ \\
Organizational & 926 & $39.1 \%$ & 145 & $33.6 \%$ & 118 & $34.3 \%$ & 663 & $41.6 \%$ \\
Classroom & 884 & $37.3 \%$ & 188 & $43.5 \%$ & 141 & $41 \%$ & 554 & $34.8 \%$ \\
\hline
\end{tabular}

Notes: 1CBE, 1st cycle of basic education; 2CBE, 2nd cycle of basic education; 3BE, 3rd cycle of basic education; $\mathrm{SE}$, secondary education; $\mathrm{AbF}$, absolute frequency; $\mathrm{AF}$, average frequency.

The personal identity category was the most frequently mentioned and shows how the participants felt close to their mental and emotional limits (P04: "I would scramble all the names! Ideas would blur in my brain!"). It also shows how demanding it is for teachers to combine their different life roles (P01: "It's always outside school time (...), and the teacher also has a family!"). For teachers of the 2nd cycle, the subcategory of coping mechanisms appeared to be of particular importance (P05: "I'm handling it because I'm being medicated!").

In the category professional identity, lack of recognition, and loss of status were the noteworthy subcategories. Although these subcategories may seem the same at first glance, it is possible to distinguish the meaning of recognition (P02: "The work a teacher does in the classroom is not of interest, it is not recognized nor valued!") from status (P11: "I consider myself as cheap labor!").

\subsection{Organizational Dimension}

The education system category was the most frequently cited organizational dimension, especially legislation, and overall bureaucracy subcategories. The frustration with bureaucracy is characterized not only by its quantity but also by the perception of its inutility (P05: "We always have to have papers going back and forth! We have a lot more bureaucracy nowadays than before. It does not serve any purpose. It's just to be filed!"). Similarly, legislation not only encompasses the negative impact of the constant legal changes (P19: "We start the year and give specific guidelines [to students and parents], and it is not the first, nor the second, not the third time that the rules of the game change in the middle of the year!"), but also the failure to understand the usefulness and benefit of those changes (P01: "A new government takes office and everything changes ... What was done already is never considered to, at least, understand what was well-done!"). The sub- 
category legislation also appears to rebound in the interpersonal relationship quality (P12: "This year we're [teachers] in a school, next year we'll be in a different one. By the time that we can get relocated to a new school, get used to the new environment and peers, we reach the 2nd semester!"). The negative relationship with peers was the most prevalent complaint in the school atmosphere (P08: "People no longer talk, hang out! They are not friends anymore!").

Table 5. Frequency of answers per category and subcategory.

\begin{tabular}{|c|c|c|c|c|c|c|c|c|c|c|c|c|}
\hline \multirow{2}{*}{$\begin{array}{c}\text { Category } \\
\text { Subcategory }\end{array}$} & \multicolumn{3}{|c|}{$\begin{array}{l}\text { Total Sample } \\
\quad(n=26)\end{array}$} & \multicolumn{3}{|c|}{$\begin{array}{c}\text { 1CBE } \\
(n=4)\end{array}$} & \multicolumn{3}{|c|}{$\begin{array}{l}2 \mathrm{CBE} \\
(n=5)\end{array}$} & \multicolumn{3}{|c|}{$\begin{array}{c}\text { 3CBE and SE } \\
(n=17)\end{array}$} \\
\hline & $\mathrm{AbF}$ & AF & RF & $\mathrm{AbF}$ & AF & RF & $\mathrm{AbF}$ & AF & RF & $\mathrm{AbF}$ & AF & RF \\
\hline \multicolumn{13}{|l|}{ Personal Identity } \\
\hline Positive management of life roles & 10 & $0.4 \%$ & $3 \%$ & 1 & $0.2 \%$ & $2 \%$ & 6 & $1.7 \%$ & $8 \%$ & 2 & $0.1 \%$ & $1 \%$ \\
\hline Negative management of life roles & 91 & $3.8 \%$ & $24 \%$ & 21 & $4.9 \%$ & $34 \%$ & 7 & $2 \%$ & $10 \%$ & 65 & $4.1 \%$ & $27 \%$ \\
\hline Coping Mechanisms & 66 & $2.8 \%$ & $17 \%$ & 7 & $1.6 \%$ & $11 \%$ & 15 & $4.4 \%$ & $21 \%$ & 44 & $2.8 \%$ & $18 \%$ \\
\hline Capabilities & 212 & $9 \%$ & $56 \%$ & 33 & $7.6 \%$ & $53 \%$ & 45 & $13.1 \%$ & $62 \%$ & 134 & $8.4 \%$ & $55 \%$ \\
\hline Sub-total & 379 & $16 \%$ & $100 \%$ & 62 & $14.4 \%$ & $100 \%$ & 73 & $21.2 \%$ & $100 \%$ & 245 & $15.4 \%$ & $100 \%$ \\
\hline \multicolumn{13}{|l|}{ Professional Identity } \\
\hline Recognition & 3 & $0.1 \%$ & $2 \%$ & 1 & $0.2 \%$ & $3 \%$ & 0 & $0 \%$ & $0 \%$ & 2 & $0.1 \%$ & $2 \%$ \\
\hline Lack of Recognition & 73 & $3.1 \%$ & $41 \%$ & 20 & $4.6 \%$ & $54 \%$ & 5 & $1.5 \%$ & $42 \%$ & 48 & $3 \%$ & $37 \%$ \\
\hline Fulfilment & 17 & $0.7 \%$ & $9 \%$ & 2 & $0.5 \%$ & $5 \%$ & 3 & $0.9 \%$ & $25 \%$ & 12 & $0.8 \%$ & $9 \%$ \\
\hline Dissatisfaction & 34 & $1.4 \%$ & $19 \%$ & 3 & $0.7 \%$ & $8 \%$ & 4 & $1.2 \%$ & $33 \%$ & 27 & $1.7 \%$ & $21 \%$ \\
\hline Loss of Status & 52 & $2.2 \%$ & $29 \%$ & 11 & $2.5 \%$ & $30 \%$ & 0 & $0 \%$ & $0 \%$ & 41 & $2.6 \%$ & $32 \%$ \\
\hline Sub-total & 179 & $7.6 \%$ & $100 \%$ & 37 & $8.6 \%$ & $100 \%$ & 12 & $3.5 \%$ & $100 \%$ & 130 & $8.2 \%$ & $100 \%$ \\
\hline \multicolumn{13}{|l|}{ School System } \\
\hline Programs & 64 & $2.7 \%$ & $17 \%$ & 16 & $3.7 \%$ & $19 \%$ & 10 & $2.9 \%$ & $23 \%$ & 38 & $2.4 \%$ & $15 \%$ \\
\hline Teachers' workload & 43 & $1.8 \%$ & $11 \%$ & 5 & $1.2 \%$ & $6 \%$ & 5 & $1.5 \%$ & $11 \%$ & 30 & $1.9 \%$ & $12 \%$ \\
\hline Students' Workload & 22 & $0.9 \%$ & $6 \%$ & 9 & $2.1 \%$ & $11 \%$ & 1 & $0.3 \%$ & $2 \%$ & 15 & $0.9 \%$ & $6 \%$ \\
\hline Overall Bureaucracy & 93 & $3.9 \%$ & $25 \%$ & 21 & $4.9 \%$ & $25 \%$ & 7 & $2 \%$ & $16 \%$ & 65 & $4.1 \%$ & $26 \%$ \\
\hline Teachers' Evaluation & 21 & $0.9 \%$ & $6 \%$ & 4 & $0.9 \%$ & $5 \%$ & 1 & $0.3 \%$ & $2 \%$ & 16 & $1 \%$ & $6 \%$ \\
\hline School Evaluation & 23 & $1 \%$ & $6 \%$ & 3 & $0.7 \%$ & $4 \%$ & 1 & $0.3 \%$ & $2 \%$ & 19 & $1.2 \%$ & $8 \%$ \\
\hline Legislation & 108 & $4.6 \%$ & $29 \%$ & 25 & $5.8 \%$ & $30 \%$ & 19 & $5.5 \%$ & $43 \%$ & 64 & $4 \%$ & $26 \%$ \\
\hline Sub-total & 374 & $15.8 \%$ & $100 \%$ & 83 & $19.2 \%$ & $100 \%$ & 44 & $12.8 \%$ & $100 \%$ & 247 & $15.5 \%$ & $100 \%$ \\
\hline \multicolumn{13}{|l|}{ School Context } \\
\hline Schedule & 50 & $2.1 \%$ & $23 \%$ & 8 & $1.9 \%$ & $32 \%$ & 11 & $3.2 \%$ & $28 \%$ & 31 & $1.9 \%$ & $20 \%$ \\
\hline Extra Activities & 86 & $3.6 \%$ & $39 \%$ & 7 & $1.6 \%$ & $28 \%$ & 18 & $5.2 \%$ & $46 \%$ & 61 & $3.8 \%$ & $40 \%$ \\
\hline School Circumstances & 28 & $1.2 \%$ & $13 \%$ & 5 & $1.2 \%$ & $20 \%$ & 2 & $0.6 \%$ & $5 \%$ & 21 & $1.3 \%$ & $14 \%$ \\
\hline Number of Classes & 17 & $0.7 \%$ & $8 \%$ & 2 & $0.5 \%$ & $8 \%$ & 2 & $0.6 \%$ & $5 \%$ & 14 & $0.9 \%$ & $9 \%$ \\
\hline Specific Bureaucracy & 37 & $1.6 \%$ & $17 \%$ & 3 & $0.7 \%$ & $12 \%$ & 6 & $1.7 \%$ & $15 \%$ & 27 & $1.7 \%$ & $18 \%$ \\
\hline Sub-total & 218 & $9.2 \%$ & $100 \%$ & 25 & $5.8 \%$ & $100 \%$ & 39 & $11.3 \%$ & $100 \%$ & 154 & $9.7 \%$ & $100 \%$ \\
\hline \multicolumn{13}{|l|}{ School Atmosphere } \\
\hline Organizational Injustice & 50 & $2.1 \%$ & $20 \%$ & 6 & $1.4 \%$ & $23 \%$ & 3 & $0.9 \%$ & $9 \%$ & 41 & $2.6 \%$ & $22 \%$ \\
\hline Positive Relationship with Peers & 20 & $0.8 \%$ & $8 \%$ & 1 & $0.2 \%$ & $4 \%$ & 8 & $2.3 \%$ & $24 \%$ & 11 & $0.7 \%$ & $6 \%$ \\
\hline Negative Relationship with Peers & 94 & $4 \%$ & $38 \%$ & 11 & $2.5 \%$ & $42 \%$ & 13 & $3.8 \%$ & $39 \%$ & 70 & $4.4 \%$ & $37 \%$ \\
\hline Positive Relationship with Principals & 12 & $0.5 \%$ & $5 \%$ & 2 & $0.5 \%$ & $8 \%$ & 3 & $0.9 \%$ & $9 \%$ & 7 & $0.4 \%$ & $4 \%$ \\
\hline Negative Relationship with Principals & 73 & $3.1 \%$ & $29 \%$ & 6 & $1.4 \%$ & $23 \%$ & 6 & $1.7 \%$ & $18 \%$ & 61 & $3.8 \%$ & $32 \%$ \\
\hline Sub-total & 249 & $10.5 \%$ & $100 \%$ & 26 & $6 \%$ & $100 \%$ & 33 & $9.6 \%$ & $100 \%$ & 190 & $11.9 \%$ & $100 \%$ \\
\hline Limitations & & & & & & & & & & & & \\
\hline Projects & 16 & $0.7 \%$ & $19 \%$ & 6 & $1.4 \%$ & $55 \%$ & 0 & $0 \%$ & $0 \%$ & 10 & $0.6 \%$ & $14 \%$ \\
\hline Lack of Autonomy & 50 & $2.1 \%$ & $59 \%$ & 4 & $0.9 \%$ & $36 \%$ & 2 & $0.6 \%$ & $100 \%$ & 44 & $2.8 \%$ & $61 \%$ \\
\hline Lobbies & 19 & $0.8 \%$ & $22 \%$ & 1 & $0.2 \%$ & $9 \%$ & 0 & $0 \%$ & $0 \%$ & 18 & $1.1 \%$ & $25 \%$ \\
\hline Sub-total & 85 & $3.6 \%$ & $100 \%$ & 11 & $2.5 \%$ & $100 \%$ & 2 & $0.6 \%$ & $100 \%$ & 72 & $4.5 \%$ & $100 \%$ \\
\hline Classroom & & & & & & & & & & & & \\
\hline Behaviors & 121 & $5.1 \%$ & $28 \%$ & 9 & $2.1 \%$ & $14 \%$ & 37 & $10.8 \%$ & $42 \%$ & 75 & $4.7 \%$ & $26 \%$ \\
\hline Management & 132 & $5.6 \%$ & $30 \%$ & 22 & $5.1 \%$ & $33 \%$ & 25 & $7.3 \%$ & $28 \%$ & 85 & $5.3 \%$ & $30 \%$ \\
\hline Teaching content & 8 & $0.3 \%$ & $2 \%$ & 0 & $0 \%$ & $0 \%$ & 0 & $0 \%$ & $0 \%$ & 8 & $0.5 \%$ & $3 \%$ \\
\hline Interruptions & 48 & $2 \%$ & $11 \%$ & 5 & $1.2 \%$ & $8 \%$ & 5 & $1.5 \%$ & $6 \%$ & 38 & $2.4 \%$ & $13 \%$ \\
\hline Climate & 77 & $3.3 \%$ & $18 \%$ & 13 & $3 \%$ & $20 \%$ & 15 & $4.4 \%$ & $17 \%$ & 49 & $3.1 \%$ & $17 \%$ \\
\hline Class & 52 & $2.2 \%$ & $12 \%$ & 17 & $3.9 \%$ & $26 \%$ & 6 & $1.7 \%$ & $7 \%$ & 29 & $1.8 \%$ & $10 \%$ \\
\hline Sub-total & 438 & $18.5 \%$ & $100 \%$ & 66 & $15.3 \%$ & $100 \%$ & 88 & $25.6 \%$ & $100 \%$ & 284 & $17.8 \%$ & $100 \%$ \\
\hline Students & & & & & & & & & & & & \\
\hline Family structure & 23 & $1 \%$ & $15 \%$ & 8 & $1.9 \%$ & $18 \%$ & 2 & $0.6 \%$ & $7 \%$ & 13 & $0.8 \%$ & $16 \%$ \\
\hline Development & 57 & $2.4 \%$ & $37 \%$ & 27 & $6.3 \%$ & $61 \%$ & 5 & $1.5 \%$ & $18 \%$ & 25 & $1.6 \%$ & $30 \%$ \\
\hline Motivation & 75 & $3.2 \%$ & $48 \%$ & 9 & $2.1 \%$ & $20 \%$ & 21 & $6.1 \%$ & $75 \%$ & 45 & $2.8 \%$ & $54 \%$ \\
\hline Sub-total & 155 & $6.5 \%$ & $100 \%$ & 44 & $10.2 \%$ & $100 \%$ & 28 & $8.1 \%$ & $100 \%$ & 83 & $5.2 \%$ & $100 \%$ \\
\hline Parents & & & & & & & & & & & & \\
\hline Positive relationship with parents & 38 & $1.6 \%$ & $16 \%$ & 10 & $2.3 \%$ & $16 \%$ & 7 & $2 \%$ & $30 \%$ & 21 & $1.3 \%$ & $14 \%$ \\
\hline Pressure & 77 & $3.3 \%$ & $33 \%$ & 12 & $2.8 \%$ & $19 \%$ & 5 & $1.5 \%$ & $22 \%$ & 59 & $3.7 \%$ & $40 \%$ \\
\hline Education & 119 & $5 \%$ & $51 \%$ & 41 & $9.5 \%$ & $65 \%$ & 11 & $3.2 \%$ & $48 \%$ & 67 & $4.2 \%$ & $46 \%$ \\
\hline Sub-total & 234 & $9.9 \%$ & $100 \%$ & 63 & $14.6 \%$ & $100 \%$ & 23 & $6.7 \%$ & $100 \%$ & 147 & $9.2 \%$ & $100 \%$ \\
\hline Society & & & & & & & & & & & & \\
\hline Values & 12 & $0.5 \%$ & $21 \%$ & 6 & $1.4 \%$ & $40 \%$ & 1 & $0.3 \%$ & $50 \%$ & 6 & $0.4 \%$ & $15 \%$ \\
\hline Mission & 45 & $1.9 \%$ & $79 \%$ & 9 & $2.1 \%$ & $60 \%$ & 1 & $0.3 \%$ & $50 \%$ & 34 & $2.1 \%$ & $85 \%$ \\
\hline Sub-total & 57 & $2.4 \%$ & $100 \%$ & 15 & $3.5 \%$ & $100 \%$ & 2 & $0.6 \%$ & $100 \%$ & 40 & $2.5 \%$ & $100 \%$ \\
\hline
\end{tabular}

Notes: $1 \mathrm{CBE}$, 1st cycle of basic education; $2 \mathrm{CBE}$, 2nd cycle of basic education; 3BE, 3rd cycle of basic education; SE, secondary education; $\mathrm{AbF}$, absolute frequency; RF, relative frequency; $\mathrm{AF}$, average frequency. Section 3.3. 
In the school context category, the extra activities subcategory was the most mentioned and conveys the dissatisfaction with the accumulation of activities or functions not directly related to teaching (P01: “The teacher doesn't clean the toilets yet, because he does everything else (...) because he does everything else!").

In the limitations category, lack of autonomy is the most mentioned subcategory and describes a type of content directly related to stipulations that limit teachers' actions (P13: "And the pressure to change the grades!? I lost count of the times grades given by me were changed!").

\subsection{Classroom Dimension}

The classroom category is the most frequent complaint, which describes teachers' strategies to manage the classroom and the students' disruptive behavior. These two subcategories are closely related since the previously mentioned teachers' strategies seem to be brought up as a reaction to the students' behavioral issues (P08: "I do a lot of expulsions"). In addition, the connection between student misbehavior and the idiosyncrasies of the school system seems to be evident (P26: "Indiscipline could be minimized if there was enough support from school to protect the teacher (...) Inside the classroom I don't have any fears, I feel good, I feel safe (...) what's beyond the classroom is out of my control!"), in particular the lack of autonomy (P06: "[Students] assume they can do anything and we cannot do anything about it!").

The description of the severity of students' behaviors allows for the grasp of its seriousness (P04: "One of my students set fire to a teacher's hair! So, you can see the kind of students I had!"). For 2nd cycle teachers, the impact of students' behavior seems to be particularly harmful (P05: "It is one of the most important questions to me: classroom indiscipline!"). For 1st cycle teachers, the classroom characteristics and students' heterogeneity are significant (P02: "Because there are so many students with so many different learning programs. And I am here thinking: "What shall I do!?").

Concerning students, lack of motivation is the most mentioned subcategory by teachers (P05: "Students' motivation is elsewhere!").

In the parents' category, teachers perceive their relationship with parents as positive, even though interaction with parents seems to be negative. The perceived pressure by parents on teachers is felt both directly (P25: "Scenes of parents storming into school and wanting to break the teachers or student's faces, are a common scenario nowadays!"), as well as indirectly (P21: "[The school board] would change the grades fearing that parents would not be happy about it!"). For teachers of 1st cycle classes, the perception of parental educational practices is significant (P14: "As long as parents do not take responsibility for what they should do, we cannot do that job here in the classroom, it is impossible!").

Lastly, mission is the subcategory most mentioned in the society category (P13: "And the school has been more and more a deposit for everything, a scapegoat for everything (...) almost feels like a factory!").

\section{Discussion}

This study intended to understand the relative importance of the personal, organizational, and classroom dimensions related to the Portuguese educational system that contribute to burnout of Portuguese teachers at different levels of education.

Overall, the variables identified in this study (e.g., life roles management, bureaucracy, extra activities, indiscipline, class size) corroborate previous research on teacher burnout [14-16,23]. The multiplicity of emerging categories and subcategories uphold the idea that school as a professional context provides multiple scenarios that contribute to teacher's exhaustion $[2,30]$. Our findings give important clues about the weight that different variables effectively have on teacher burnout. 


\subsection{Burnout Dimensions}

The school environment has been identified as one of the most critical organizational variables [31] concerning the quality of the social relationships in the workplace [32]. Literature suggests that the perceived support from school principals is more critical for teachers' well-being than the perceived support from peers, because principals interfere with personal goals [33-35]. Nevertheless, our results suggest that the deterioration of relationships between peers is a more significant contributing factor to burnout than the deterioration of relationships between teachers and principals. Therefore, the quality of the relationships among school actors has a specific impact on teachers' well-being,

Among the school system attributes, the legislation seems to be an essential source of tension in teachers [36]. However, our results suggest that legislation gains significance only when considering the implementation of several ongoing changes. For teachers interviewed in this study, those changes give rise to feelings of instability and uncertainty. In the literature, few studies have considered the impact of the ongoing legal changes in teachers' burnout [36]. The importance of this variable in the Portuguese context appears to stem from the countless changes implemented in Portugal's school system in recent years [37].

Our study suggests that teachers struggle the most in managing the classroom context. Recent data from the Teaching and Learning International Survey 2018 [38] show that just $46.7 \%$ of Portuguese teachers feel confident enough to run the classroom. Data from the same report [38] show that only $73.5 \%$ of the time spent in the Portuguese classroom is dedicated to teaching/learning tasks. This result suggests a significant amount of wasted time, possibly with discipline issues or tasks not directly related to teaching. In our study, most classroom interruptions appeared to be caused by student misbehavior (P24: "Student misbehavior is always there. You cannot teach!"), which has been identified as the main culprit for teacher exhaustion in Portugal [11,36]. Furthermore, the dissatisfaction with extracurricular activities suggests that the tasks not directly related to teaching are perceived as risk variables to teacher exhaustion [15].

It is in the classroom context that variables related to parents surface. The literature highlights the importance of parent-teacher relationships [2,39]. In our study, teachers tended to classify their relationships with parents as being positive. However, participants also identified parents as an important source of stress. This reference suggests that the quality of the relationships between teachers and parents does not allow us to understand the significant impact of parents' role in teachers' well-being. It is possible that the perception of the lack of autonomy (P10: "We like to have our autonomy in scientific terms, educational ... But even in the scientific section parents interfere!") and the leverage and pressure from parents on teachers (P14: "People are terrified with parents. All it takes to incite panic is a parent complaining about a colleague!") force teachers into adopting neutral stances to avoid conflict with parents. The job-demand-control model may aid with understanding these results [40]. According to this model, autonomy is an essential resource for individuals to positively handle job-related demands and, consequently, reduce emotional exhaustion $[39,41]$.

In addition, we found other variables linked to parents that seem to significantly contribute to teachers' exhaustion (e.g., educational practices, students' family structure). In the literature, however, the role of these variables has been poorly explored, because they are indirectly correlated with other variables (i.e., students). Thus, it might be hard to identify those variables in quantitative studies that tend to restrict the participants' answers to preconceived questions.

Broadly, results corroborate the literature [41,42], proposing that the organizational dimension is the most relevant to the development and prevalence of burnout. Nevertheless, our results emphasize the importance of the individual's perception of available resources for managing burnout regarding the personal dimension. Our study shows that burned out teachers perceive an imbalance between teaching demands (i.e., extracurricular activities) and the lack of resources to deal with those demands (i.e., skills). This result 
can be explained by the Job Demand and Resources Model of [7]. According to this model, the greater the imbalance between the demands and perceived resources, the higher the stress levels. In our study, adopting palliative strategies (e.g., psychiatric medication) suggests that Portuguese teachers struggle to cope with their perceived teaching demands. This predicator bolsters the need for preventative measures with teachers, targeting the development of specific coping competencies to deal with the demands and challenges of the school environment.

Another important finding of the personal dimension is that, contrary to findings in the literature [43], salary is not a significant source of tension. Similar results were found in a qualitative study by [28], hinting at the importance of differentiating the type of rewards (i.e., material vs. non-material) that effectively contribute to or mitigate teacher burnout. Our study also suggests that non-material rewards (e.g., recognition) have only relative importance compared to other variables.

Finally, this study also identified a set of abstract variables, such as social values and school mission, which suggest that burned out teachers tend to generalize their negative perspective at a macro level, further intensifying the negative impact of burnout. The contribution of these values to burnout has been associated with individuals' cognitive and emotional calculus regarding the gap between their values and the organizational ones [44].

\subsection{Burnout and Teaching Levels}

Results suggest that the categories that contribute to teacher burnout are identical across teaching levels. Nonetheless, the relevance of each category may vary depending on the teaching level. For instance, the classroom dimension seems to be more relevant to teachers of the 1st and 2nd cycles. Moreover, for 1st cycle teachers, the student workload, education, and development subcategories were notably more frequently mentioned. This outcome may be due to the intrinsic characteristics of mono-grade teaching, consisting of prolonged daily contact with students and more regular teacher-parent interactions [18].

\section{Conclusions}

This study offers insights into different variables' contributions to Portuguese teachers' burnout and the impact of each variable. Our findings highlight the multidimensional nature of burnout and emphasize the need to adopt a holistic approach to research and intervention programs on burnout. It is crucial to consider the simultaneous action, dynamics, and interdependency among variables, to be able to understand the progress and prevalence of burnout in teachers.

The results of this study allow us to contribute to the understanding of the phenomenon of burnout in the teaching profession, based on a phenomenological characterization that reflects the individual experience and, therefore, can complement the limitations of the available quantitative research. Our study identified poorly studied or even neglected variables via inductive analysis, whose roles should be explored in future studies on teacher burnout. These neglected variables include the perception of educational practices, parents' power, life and social values, or the school's mission. The emergence of these variables may have resulted from the qualitative methodology used in this study, allowing teachers to reflect about their burnout experience thoroughly $[3,26]$.

\section{Limitations}

This study presents limitations that should be considered in the analysis of results. Although the inter-judge agreement guaranteed the integrity of the qualitative research, the researchers' unique interpretation may be somehow echoed in the data analysis. Even though there is a predominance of women, either in the teaching profession (more than $72 \%$ in Portugal) [45] or in the burnout condition [8], we cannot make gender comparisons because the sample in this study was predominantly female. The findings within the various teaching levels should also be reviewed with caution, given the small size of the sub-samples. 
Author Contributions: Conceptualization, A.I.M., J.L. and C.O.; Formal analysis, A.I.M., J.L. and C.O.; Investigation, A.I.M., J.L. and C.O.; Methodology, A.I.M., J.L. and C.O.; Supervision, J.L. and C.O.; Validation, A.I.M., J.L. and C.O.; Visualization, A.I.M., J.L. and C.O.; Writing-original draft, A.I.M.; Writing-review and editing, A.I.M., J.L. and C.O. All authors have read and agreed to the published version of the manuscript.

Funding: This research received no external funding.

Institutional Review Board Statement: The study was conducted according to the guidelines of the Declaration of Helsinki and approved by the Ethics Subcommittee for Social and Human Sciences of the University of Minho (SECSH 020/2017).

Informed Consent Statement: Informed consent was obtained from all subjects involved in the study.

Data Availability Statement: The data presented in this study are available on request from the corresponding author. The data are not publicly available due to privacy and ethical reasons.

Conflicts of Interest: The authors declare no conflict of interest.

\section{References}

1. Sterling, P. Allostasis: A model of predictive regulation. Physiol. Behav. 2012, 106, 5-15. [CrossRef]

2. Psyhältö, K.; Pietarinen, J.; Salmela-Aro, K. Teacher-working-environment fit as framework for burnout experienced by Finnish teachers. Teach. Teach. Educ. 2011, 27, 1101-1110. [CrossRef]

3. Maslach, C.; Leiter, M.P. It's time to take action on burnout. Burn. Res. 2015, 2, iv-v. [CrossRef]

4. Pietarinen, J.; Psyhältö, K.; Soini, T.; Salmela-Aro, K. Reducing teacher burnout: A socio-contextual approach. Teach. Teach. Educ. 2013, 35, 62-72. [CrossRef]

5. Skaalvik, E.M.; Skaalvik, S. Does school context matter? Relations with teacher burnout and job satisfaction. Teach. Teach. Educ. 2009, 25, 518-524. [CrossRef]

6. Aronsson, G.; Theorell, T.; Grape, T.; Hammarström, A.; Hogstedt, C.; Marteinsdottir, I.; Skoog, I.; Träskman-Bendz, L.; Hall, C. A systematic review including meta-analysis of work environment and burnout symptoms. BMC Public Health 2017, 17, 264. [CrossRef]

7. Demerouti, E.; Bakker, A.; Nachreiner, F.; Schaufeli, W. The job demands-resources model of burnout. J. Appl. Psychol. 2001, 86, 499-512. [CrossRef]

8. Mota, A.I.; Lopes, J.; Oliveira, C. Burnout in Portuguese teachers: A systematic review. Eur. J. Educ. Res. 2021, 10, 693-703.

9. Fiorilli, C.; Albanese, O.; Gabola, P.; Pepe, A. Teachers' emotional competence and social support: Assessing the mediating role of teacher burnout. Scand. J. Educ. Res. 2017, 61, 127-138. [CrossRef]

10. Helou, M.E.; Nabhani, M.; Bahous, R. Teachers' views on causes leading to their burnout. Sch. Leadersh. Manag. 2016, 36, 551-567. [CrossRef]

11. Pinto, A.M.; Lima, M.L.; Silva, A.L. Fuentes de estrés, burnout y estratégias de coping en profesores portugueses [Stress sources, burnout and coping among Portuguese teachers]. Rev. Psicol. Trab. Organ. 2005, 21, 125-143.

12. Arvidsson, I.; Leo, U.; Larsson, A.; Hakansson, C.; Persson, R.; Björk, J. Burnout among school teachers: Quantitative and qualitative results from a follow-up study in southern Sweden. BMC Public Health 2019, 19, 655. [CrossRef] [PubMed]

13. Kangas-Dick, K.; O'Shaughnessy, E. Interventions that promote resilience among teachers: A systematic review of the literature. Int. J. Sch. Educ. Psychol. 2020, 8, 131-146. [CrossRef]

14. Carlotto, M.S.; Palazzo, L.S. Síndrome de burnout e fatores associados: Um estudo epidemiológico com professores [Factors associated with burnout's syndrome: An epidemiological study of teachers]. Cad. Saude Publica 2006, 22, 117-126. [CrossRef]

15. Lawrence, D.F.; Loi, N.M.; Gudex, B.W. Understanding the relationship between work intensification and burnout in secondary teachers. Teach. Teach. Theory Pract. 2019, 25, 189-199. [CrossRef]

16. Consiglio, C.; Laura, B.; Vecchione, M.; Maslach, C. Self-efficacy, perceptions of context, and burnout: A multilevel study on nurses. Med. Lav. 2014, 105, 255-268.

17. Day, A.; Leiter, M. The good and the bad of working relationships: Implications for burnout. In Burnout at Work: A Psychological Perspective; Leiter, M., Bakker, A., Maslach, C., Eds.; Psychology Press: London, UK, 2014; pp. 56-79.

18. Martin, N.K.; Sass, D.A.; Schmitt, T.A. Teacher efficacy in student engagement, instructional management, student stressors, and burnout: A theoretical model using in-class variables to predict teachers' intent-to-leave. Teach. Teach. Educ. 2012, 28, 546-559. [CrossRef]

19. Carlotto, M.S. Síndrome de burnout: Diferenças segundo níveis de ensino [Burnout syndrome: Differences according to education levels]. Psico 2010, 41, 495-502.

20. Tatar, M.; Horenczyk, G. Diversity-related burnout among teachers. Teach. Teach. Educ. 2003, 19, 387-408. [CrossRef]

21. Rajendran, N.; Watt, H.M.; Richardson, P. Teacher burnout and turnover intent. Aust. Educ. Res. 2020, 47, 477-500. [CrossRef]

22. Aloe, A.; Shisler, S.; Norris, B.; Nickerson, A.; Rinker, T. A multivariate meta-analysis of student misbehaviour and teacher burnout. Educ. Res. Rev. 2014, 12, 30-44. [CrossRef]

23. Shen, B.; McCaughtry, N.; Martin, J.; Garn, A.; Kulik, N.; Fahlman, M. The relationship between teacher burnout and student motivation. Br. J. Educ. Psychol. 2015, 85, 519-532. [CrossRef] 
24. Stoeber, J.; Rennert, D. Perfectionism in school teachers: Relations with stress, appraisals, coping styles, and burnout. Anxiety Stress Coping 2008, 21, 37-53. [CrossRef] [PubMed]

25. Gomes, A.R.; Faria, S.; Gonçalves, M. Cognitive appraisal as a mediator in the relationship between stress and burnout. Work Stress 2013, 27, 351-367. [CrossRef]

26. Busetto, L.; Wck, W.; Gumbinger, C. How to use and assess qualitative research methods. Neurol. Res. Pract. 2020, 2, 1-10. [CrossRef] [PubMed]

27. Maxwell, J.A. Using numbers in qualitative research. Qual. Inq. 2010, 16, 1-8. [CrossRef]

28. Bardin, L. Análide de Conteúdo [Content Analysis], 3rd ed.; Edições 70: Lisboa, Portugal, 2004.

29. Fonseca, R.; Silva, P.; Silva, R. Acordo inter-juízes: O caso do coeficiente kappa [The interrater agreement: Kappa's coefficient]. Laboratório Psicol. 2007, 5, 81-90.

30. Shernoff, E.; Mehta, T.; Atkins, M.; Torf, R.; Spencer, J. A qualitative study of the sources and impact of stress among urban teachers. School Ment. Health 2011, 3, 59-69. [CrossRef]

31. Droogenbroeck, F.; Spruyt, B.; Vanroelen, C. Burnout among senior teachers: Investigating the role of workload and interpersonal relationships at work. Teach. Teach. Educ. 2014, 43, 99-109. [CrossRef]

32. Leiter, M.P.; Maslach, C. Latent burnout profiles: A new approach to understanding the burnout experience. Burn. Res. 2016, 3, 89-100. [CrossRef]

33. Charoensukmongkol, P.; Moqbel, M.; Gutierrez-Wirsching, S. The role of co-worker and supervisor support on job burnout and job satisfaction. J. Adv. Manag. Res. 2016, 13. [CrossRef]

34. Dysvik, A.; Kuvaas, B. Perceived supervisor support climate, perceived investment in employee development climate, and business-unit performance. Hum. Resour. Manag. 2012, 51, 651-664. [CrossRef]

35. Halbesleben, J.; Wheeler, A. To invest or not? The role of co-worker support and trust in daily reciprocal gain spirals of helping behaviour. J. Manag. 2012, 41, 1628-1650.

36. Gomes, A.R.; Peixoto, A.; Pacheco, R.; Silva, M. Stress ocupacional e alteração do Estatuto da Carreira Docente português [Occupational stress and the change to the Portuguese statute of the teaching career]. Educ. Pesqui. 2012, 38, 357-371. [CrossRef]

37. Crato, N. Curriculum and educational reforms in Portugal: An analysis on why and how students' knowledge and skills improved. In Audacious Education Purposes; Reimers, F., Ed.; Springer: Cham, Switzerland, 2020; pp. $209-231$.

38. OECD. TALIS 2018 Results (Volume I). Teachers and School Leaders as Lifelong Learners; OECD Publishing: Paris, France, 2019.

39. Skaalvik, E.M.; Skaalvik, S. Teacher self-efficacy and teacher burnout: A study of relations. Teach. Teach. Educ. 2010, 26, 1059-1069. [CrossRef]

40. Karasek, R.; Theorell, T. Healthy Work: Stress, Productivity, and the Reconstruction of Working Life; Basic Books: New York, NY, USA, 1990.

41. Maslach, C.; Schaufeli, W.B.; Leiter, M.P. Job burnout. Annu. Rev. Psychol. 2001, 52, 397-422. [CrossRef]

42. Fernet, C.; Guay, F.; Senécal, C.; Austin, C. Predicting intraindividual changes in teacher burnout: The role of perceived school environment and motivational factors. Teach. Teach. Educ. 2012, 28, 514-525. [CrossRef]

43. Hanushek, E.; Kain, E.; Rivkin, S. Why public schools lose teachers. J. Hum. Resour. 2001, 39, 326-354. [CrossRef]

44. Maslach, C.; Leiter, M.P. Understanding the burnout experience: Recent research and its implications for psychiatry. World Psychiatry 2016, 15, 103-111. [CrossRef]

45. PORDATA. Docentes do Sexo Feminino em \% dos Docentes em Exercício nos Ensinos Pré-Escolar, Básico e Secundário: Total e por Nível de Ensino; Fundação Francisco Manuel dos Santos: Lisboa, Portugal, 2020. 